\title{
On the minerals of the auriferous districts of Wicklow
}

\section{William Mallet Esq.}

To cite this article: William Mallet Esq. (1850) On the minerals of the auriferous districts of Wicklow, Philosophical Magazine Series 3, 37:251, 392-394, DOI: $10.1080 / 14786445008646635$

To link to this article: http://dx.doi.org/10.1080/14786445008646635

曲 Published online: 30 Apr 2009.

Submit your article to this journal \lceil

Џll Article views: 4

Q View related articles $\sqsubset$ 


\section{[ 392$]$ \\ LIII. Intelligence and Miscellaneous Articles.}

\section{ON THE MINERALS OF THE AURIFEROUS DISTRICTS OF WICK- LOW. BY WILLIAM MAILET, ESQ.}

r TE circumstances attending the original discovery of native gold in the beds of some of the streams of the County of Wicklow, have been already often detailed, and will therefore need but a brief repetition. The source of the auriferous streams is the mountain Croghan Kinshela, whose summit forms a portion of the boundary between the counties of Wicklow and Wexford. The stream from which most of the gold has been obtained rises on the north-east side of this mountain, and flowing down one of the glens with which that part of the country is intersected in almost every direction, joins the Aughrim river, a little above the confluence of the latter stream with the Avonmore. It receives several smaller streams at different parts of its course, in all of which some gold appears to have been found, though in general in such small quantity as not to repay the cost of its extraction.

Although this part of the country, since it has been known to be auriferous, has been an object of some attraction to mineralogists, but little attention seems to have been directed to the other minerals which are to be found accompanying the gold in the alluvial deposits. These. however, are interesting, not only from their number and variety, but also from the occurrence amongst them of some of the rarer species, which do not appear to have been noticed in any other locality in Ireland. The following minerals were obtained from a considerable mass of sand and gravel taken from various parts of the bed of the principal stream :-

Gold.

Platina.

Tinstone.

Magnetic oxide of iron.

Micaceous iron.

Red iron ochre.

Hydrous peroxide of iron.

Common clay ironstone.

Iron pyrites.

Titaniferous iron.

Wolfram.

Oxide of manganese.

Copper pyrites.
Galena.

Sulphuret of molybdenum.

Sapphire.

Topaz.

Zircon.

Garnet (two varieties).

Quartz.

Prase.

Augite.

Chlorite.

Felspar.

Mica.

The author has since observed, in addition to those here mentioned, arsenical iron, in small fragments, and also spinelle. The latter occurs in very small grains along with the second variety of garnet, from which it is readily distinguished by its peculiar purplishred colour.

Gold.-This mineral occurs here in probably its most beautiful form. It possesses the true golden yellow colour and metallic lustre 
which characterize the metal, and, owing to the attrition to which it has been subjected, generally presents a beautifully brilliant surface. It occurs in grains of all sizes, from the smallest spangle up to a mass weighing twenty-two ounces, the largest hitherto found. 'The specific gravity of some small grains Mr. Mallet found to be 16.342 . The analysis of these grains gave-

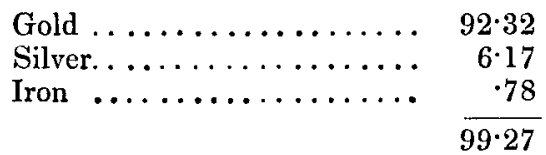

This is equivalent (neglecting the iron) to $8 \frac{1}{4}$ atoms of gold and 1 of silver.

Platina.-Mixed with the gold are some very small flattened grains of a white colour and metallic lustre, which, as far as their minute size permitted an examination, appear to present all the characters of platina. They are infusible before the blowpipe, and insoluble in nitric acid, but dissolve in aqua-regia. Their occurrence intermixed with the gold when all other minerals have been washed off, is a proof of their high specific gravity*.

Tinstone. - The occurrence of this mineral in the sand is mentioned by Weaver in his reports on the gold-stream-works, but he does not seem to have been at all aware of the large quantities in which it exists. From the comparatively small portion $f$ of sand which the author had an opportunity of examining, he obtained about $3 \frac{1}{2}$ pounds of stream tin; a portion of which being reduced, yielded an ingot, which, when refined by a second fusion, is hardly inferior to the finest grain tin + . Should this mineral be found in the mass of the sand in a quantity at all approaching that in which it existed in the specimen from which this was obtained, it would probably richly repay the labour and expense of its collection and smelting. From the small quantity in which other minerals of high specific gravity exist in the sand, and the constant supply of water, very little difficulty would be experienced in separating it from the rest of the sand; and the almost total absence of arsenic and lead would render it extremely easy to obtain from it metallic tin of the very first quality. The mineral itself occurs in grains varying in size from fine sand up to pebbles of half an inch in diameter, and for the most part of a dark brown colour, with some fragments of various tints of yellow and red; some presenting the peculiar appearance to which the name "wood tin" has been given. All these varieties are slightly translucent, some of them highly so. Many of them present distinct traces of the obtuse octohedron, the same

* It is to be wished that the existence of platina had been more fully ascertained.-Ev. Phil. Mag.

+ The exact weight of the specimen examined the author does not know, but thinks it certainly did not exceed $150 \mathrm{lbs}$.

$\ddagger$ The specimen smelted in this experiment yielded about 61 per cent. of tin ; but more would be obtained on the great scale, as in this case no pains were taken to extract the tin remaining in the scoriæ. 
with a short four-sided prism interposed between the two pyramids, and the latter of these with various truncations of its angles and edges. The specific gravity of some picked crystals was 6.753. A careful analysis of this tinstone gave as its constituents-

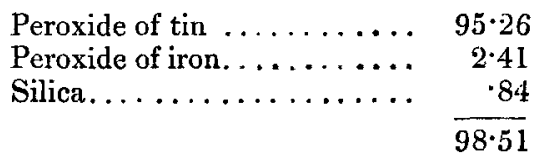

The greater number of the minerals here enumerated are mentioned by $\mathrm{Mr}$. Weaver in his reports to Government on the district, and which are to be found in the Transactions of the Royal Dublin Society; but some of them, the author believes, have not been noticed before, at least he has seen no published account of the occurrence in this locality of platina, titanic iron, sulphuret of molybdenum, topaz, zircon, the small manganesian garnets, or augite. Hence it seemed interesting, while noticing these, to collect into a uniform and as far as possible complete list, all the scattered notices of the mineral wealth of this particular district, which are to be found in $\mathrm{Mr}$. Weaver's papers already referred to, and elsewhere.

The principal point, however, with respect to the examination of these minerals, which appears to merit further and more particular attention, is the fact of the existence of tinstone in such considerable quantity in these auriferous streams; - a fact which would seem to indicate the probable existence somewhere in the surrounding district, of masses of the ore of this valuable metal of great extent, and possibly forming the continuation, on this side of the Channel, of those vast deposits which have contributed to furnish occupation and support to the inhabitants of Cornwall for more than two thousand years.-Transactions of the Geological Society of Dublin.

\section{ON PYROGLYCERIN. BY M. SOBRERO.}

M. Sobrero has given the above name to a compound which he obtained by treating glycerin with a mixture of nitric and sulphuric acids, in the same proportions as for preparing gun-cotton. This product is liquid, and explodes very violently; its taste is very distinctly bitter, and is a very active poison; two or three centigrammes immediately kill a dog. It is a powerful oxidizer; mixed with nitric acid, it, forms a kind of aqua regia. It has not been analysed, but is suspected to contain nitric acid.-Journ. de Pharm., Avril 1850.

\section{PREPakation of sulphurous aCID. BY M. Boutigny.}

The author having occasion to prepare a large quantity of sulphurous acid, advantageously employed a cast-iron apparatus for this purpose in decomposing sulphuric acid by charcoal. In this operation the iron was not at all acted upon. Although many manufac- 